\title{
The Impact of Sport Tourism as a Tourism Sector Analysis in Kepulauan Seribu, Indonesia
}

\author{
Heni Widyaningsih*, Eva Yulianti, Hermawan Hernawan, Yusmawati Yusmawati \\ Fakultas Ilmu Olahraga \\ Universitas Negeri Jakarta \\ Jakarta, Indonesia \\ *heniwidyaningsih@unj.ac.id, eyulianti@unj.ac.id, hernawan@unj.ac.id
}

\begin{abstract}
Sports tourism is now a popular tourist activity in the tourism industry sector. The economic and social impact resulting from the development of this activity is quite large for the welfare of the surrounding community and also the development of sports tourism. This study aims to analyse the economic impact caused by the development of sports tourism in Kepulauan Seribu. The method used is a survey method, namely by conducting interviews with representatives of local governments, surrounding communities, tourism agents and tourists. Through the data obtained from various sources, information about the socio-economic conditions of the development of sports tourism activities in Kepulauan Seribu will be obtained. Thus the information obtained can be used as a basis for the central and regional governments to develop Kepulauan Seribu region, especially in the marine tourism sector.
\end{abstract}

Keywords: sport tourism, multiplier effect, socioeconomic public, Kepulauan Seribu

\section{INTRODUCTION}

Within the framework of regional autonomy, DKI Jakarta Regional Government is obliged to consistently manage the potentials of Kepulauan Seribu in order to be developed. One of the potentials which owned by Kepulauan Seribu is the development and management of the tourism sector, which is expected to increase regional income and improve community welfare. The development of tourism potential, especially marine tourism in Kepulauan Seribu will be a multiplier effects for other sectors such as community income as well as social and cultural changes in community. Tourism development should have given positive impact on the surrounding community. The connection in this matter is to be able to change social behaviour for the better, economic improvement, and cultural diversity which will be a means of promotion as well as attraction for tourists who will visit. Thus, this will increase the foreign exchange income of the state and the community in the tourist objects location [1].

The area condition that surrounded by more beaches and waters has made Kepulauan Seribu to become the main fish supplier area for Jakarta and Tangerang regions. Other advantage of this condition has made Kepulauan Seribu as a marine tourism destination that offers the beauty of the coast and underwater panoramas that can attract tourists both from domestic and overseas. Therefore, it can be said that
Kepulauan Seribu are included as an area that plays a role of the tourism industry in Indonesia which offers sports tourism. Meanwhile according to Pitts, sports tourism is defined as a specific travel outside of the usual environment for either passive or active involvement in competitive sport where sport is the prime motivational reason for travel and the touristic or leisure element may act to reinforce the overall experience [2]. Another definition worth noting explains sport tourism as a combination of sports activities and travel. From a sport marketing and sport management perspective, it consists of two broad categories of products: a) sports participation travel (travel for the purpose of participating in a sports, recreation, leisure or fitness activity); and b) sports spectatorial travel (travel for the purpose of spectating sports, recreation, leisure or fitness activities or events)." Sports tourism is tourism activities that carried out through fun sports activities, which generally carried out in the area of tourist attractions. Sports tourism is one kind of tourism activities which the development is quite rapid in our country, especially in the tourism areas of beaches and islands. Types of tourism activities that included into the category of sports tourism activities for examples are Hiking, Rafting, Paragliding, Water Ski, Fishing, Swimming, Billiard, Golf, Diving, Free Diving, etc.

According to G. Jennings, water-based tourism relates to any touristic activity (see definition below) undertaken in or in relation to water resources, such as lakes, dams, canals, creeks, streams, rivers, canals, waterways, marine coastal zones, seas, oceans, and ice-associated areas [3]. This can be interpreted that water-based tourism is an activity or tourism activity which carried out in a location that related to water resources such as lakes, reservoirs, canals, rivers, waterways, coastal areas of the sea, sea, ocean, and ice regions.

The development of regional potential that leads into the development of the tourism sector in Kepulauan Seribu gives an economic impact and cultural change. The economic impact of developing regional potential has become one of the marine and sports tourism destinations in DKI Jakarta Province. Kepulauan Seribu have the extraordinary natural potential with sloping beaches that can be developed in the tourism sector especially marine tourism, and also has the potential as the athlete's shed for aquatic sports (swimming, synchronized swimming, platform diving, and water polo), as well as rowing 
TABLE I. SOCIO-ECONOMIC IN KEPULAUAN SERIBU

and diving. Coastal society in Kepulauan Seribu has more opportunities to do activities in water, especially children [4].

Tourism consists in small and medium businesses with rapidly changing consumer demand/expectation and constant innovation. So, the entrepreneurs are those who may contribute at the economic and social development of the local communities, assuring a balance in a historical period when we assist at the increasing influence of the transnational companies [5]. With the development of the region in the tourism sector, it also develops the trade sector which is engaged in lodging services and trade in consumption as well as sports activities, especially water sports. The problem examined in this study is how much the increase in sports activities especially water sports as a result of changes and the development of the marine tourism sector in Kepulauan Seribu region.

\section{METHOD}

This study uses descriptive method to reveal the socioeconomic phenomenon of community life in Kepulauan Seribu. Descriptive method is a method used to examine the status of a human being, an object, a condition, a system of thought or an event. According to Nazir, descriptive research is a proper search because it has a systematic, factual and accurate depiction regarding the facts, nature and relationships between phenomenons's investigated [6]. To measure the multiplier value from the impact of changes (multiplier effects) by using changes in Marginal Propensity to Consume (MPC) from Keynes consumption theory is with the following conditions:

- If the multiplier value (multiplier effects) is less or equal to zero $(\leq 0)$, then the tourist location in Kepulauan Seribu has not provided an economic impact on sports tourism activities.

- If the multiplier value (multiplier effects) is between zero and one $(0<\mathrm{k}<1)$, then the tourist location in Kepulauan Seribu has provided a low economic impact on sports tourism activities.

- If the multiplier value (multiplier effects) is more or equal to one $(\geq 1)$, then the tourist location in Kepulauan Seribu has provided an economic impact on sports tourism activities.

\section{RESULT AND DISCUSSION}

\section{A. Result}

The results of this study are the information on socioeconomic changes in Kepulauan Seribu and the multiplier effects of sports tourism on the income per capita of Kepulauan Seribu community. The community in Kepulauan Seribu experience economic changes as a result of the increasingly crowded tourist arrivals. Based on secondary data from the Central Statistics Agency (Badan Pusat Statistik). That data can be seen in the following tabel 1 .

\begin{tabular}{|l|l|l|l|}
\hline & \multicolumn{1}{|c|}{$\mathbf{2 0 1 6}$} & \multicolumn{1}{c|}{$\mathbf{2 0 1 8}$} & \% \\
\hline Resort & 7 & 10 & 30 \\
\hline Homestay & 322 & 661 & 50 \\
\hline Foreign tourist & 24.517 & 28.417 & 13,7 \\
\hline Restorant who have lisence & 56 & 58 & 3,5 \\
\hline
\end{tabular}

Central Statistics Agency, 2018

The number of resorts built in Kepulauan Seribu continued to increase by 30\%; from 2016 until 2018; 7 resorts increased to 10 resorts. This increment is in line with the increasing number of tourists coming. Tourists who come to Kepulauan Seribu are foreign tourists and domestic tourists. In 2018, foreign tourists reached 28,417 tourists and had increased of $13.7 \%$ compared to 2016 which reached 24,517 tourists, while domestic tourists reached 748,591 tourists. The increase in tourists visiting from year to year is accompanied by the increase in the provision of homestays. In 2016, the number of homestays increased rapidly (more than $50 \%$ ) by the number of 661 homestays compared to the previous year which were only 322 homestays. However, the increase in the number of tourists and lodging or homestays is not accompanied by the availability of restaurants. Restaurants tended to be stable from 2015 to 2018 as 56 restaurants have had business licenses. The consumption needs for tourists are provided by home caterers in collaboration with travel agents that offer tour packages. The calculation result of the multiplier effects that occurred from sports tourism activities in Kepulauan Seribu towards an increase in community income is 1.05 . The value of the multiplier effects is obtained by comparing changes in income per capita with changes in public consumption. With the value of 1.05 in multiplier effects, it shows that the location of sports tourism in Kepulauan Seribu still has a low impact on increasing income from the surrounding community.

\section{B. Discussion}

There are not many people in the Kepulauan Seribu realize that their area of residence is a potential area for other fields such as sports. Most children in the Kepulauan Seribu can swim and are even able to dive and hold their breath in water but still lack good swimming techniques. These advantages are considered a natural thing for coastal communities, but it is unfortunate if the great potential is not directed as superior seeds as athletes and do not receive guidance from the government [4].

Kepulauan Seribu region can be made as a major destination that has great potential for recreation and recreational water sports. This is very possible because Kepulauan Seribu have potential in natural beauty such as coastal scenery with white sand, sunset moments and underwater beauty with coral and coral reefs that are still quite good. In addition, Kepulauan Seribu have already had sufficient infrastructure to support tourism activities for inhabited islands such as electricity supply, clean water, homestays and adequate restaurants.

When viewed from the socio-economic viewpoint, Kepulauan Seribu community is mostly fishermen, so that tourism activities are only their additional. This means that the community in Kepulauan Seribu has not had high enthusiasm 
still very small at 1.05 . There are several factors that cause the

in supporting tourism activities, for instance it is shown by the still small number of people who provide souvenirs and culinary with Kepulauan Seribu characteristics. The facilities used for sports tourism are provided by local community, for example diving and snorkelling equipment's such as safety vests or buoys oxygen tanks for diving and bicycles to enjoy the panoramic beauty of the beach. Therefore, the community in Kepulauan Seribu gets additional income from the tourism sector and sports tourism.

In another case, travel agents have quite big role in tourism activities, but most of them are not from Kepulauan Seribu community. However, the existence of travel agents can change the motivation of some people in the community to provide their home as a homestays, take their time to prepare catering or consumption and rent out their boats for the needs of tourists who come.

\section{CONCLUSION}

Based on the data and discussion in this study, it can be concluded that Kepulauan Seribu region physically has increased from year to year. This is shown by the increasing number of people in the community that provide lodgings or homestays for tourists. However, the value of the multiplier effect from the existence of sports tourism on public welfare is value of this multiplier effect, namely (1) limitations of researchers in exploring data, (2) most of tourists who come to Kepulauan Seribu want to enjoy the coastal panorama, waiting for the sunset, and (3) only a small number of tourists who come to do water sports such as diving which indeed require special skills and also the courage of the tourists themselves.

\section{REFERENCES}

[1] I.G. Pitana, Pengantar Ilmu Pariwisata, Yogyakarta: CV. Andi, 2009.

[2] B.G. Pitts, "Sport Tourism and Niche Market," Journal of Vacation Marketing, vol. 1, pp. 31-50, 1997.

[3] G. Jenning, Water-Base Tourism, Sport, Leissure and Recreation Experiencess, Elssevier Ltd, 2006.

[4] H. Widyaningsih, A Asmawi, and J.A. Tangkudung, "The implementation of physical education learning based on local excellence," Journal of Physics: Conference Series, vol. 1318(1), pp. 04, 2019.

[5] S. Rusu, L.M. Csorba, R. Cureteanu, and F.L. Isac, "Tourism Entrepreneurship and its Role in the Activity of SMEs in Romania," Journal of Economics and Business Research, vol. 18(2), pp. 23-32, 2012.

[6] M. Nazir, Metode Penelitian, Jakarta : Ghalia Indonesia, 2003. 